\title{
Integrating Internet-Based Language Laboratory in Teaching Intensive Reading at Non-English-Majored-Graduate Level
}

\author{
Yougen Lou' ${ }^{1}$, Pei Xu${ }^{2}$ \\ ${ }^{1}$ School of Foreign Studies, Yangtze University, Jingzhou, China \\ ${ }^{2}$ Paotong Elementary School, Wuhan, China \\ Email: louyougen@163.com, 308275648@qq.com
}

Received 24 July 2015; accepted 15 August 2015; published 19 August 2015

Copyright (C) 2015 by authors and Scientific Research Publishing Inc.

This work is licensed under the Creative Commons Attribution International License (CC BY). http://creativecommons.org/licenses/by/4.0/

(c) (i) Open Access

\begin{abstract}
This paper reviewed a one-term experiment on integrating internet-based language laboratory (IBLL) in teaching intensive reading to first-year non-English-majored graduate students from Yangtze University. Subjects in this study consisted of 58 non-English-majored graduate students in the control group (CG) and 58 non-English-majored graduate students in the experimental group (EG). The results showed that 1 ) compared with a teacher-dominated approach for CG, internetbased language laboratory English instruction method for EG did a better job in enhancing students' productive skills; 2) there were significant differences between males in CG and EG, and females in CG and EG.
\end{abstract}

\section{Keywords}

Internet-Based Language Laboratory, Intensive Reading, Non-English-Majored Graduate Students, Level

\section{Introduction}

In the past few years, most key universities have enlarged their enrollment every year (Wang et al., 2003), which has given rise to a serious shortage of English teachers. In order to solve this problem, most universities and colleges have implemented large-size group teaching. However, in the large-size class, students are short of opportunities to practice English they learned. And students will have no opportunity to enhance English productive skills of speaking, writing and translating in a teacher-centered classroom. Faced the problem, different 
universities and colleges have taken different measure to solve it in China. For example, in 1998, an experiment with computer-assisted language learning (CALL) was conducted by Liu and Jia to teach their non-Englishmajored graduate students by using the CD-Rom version of the college English textbook in a university in Guangzhou. Another example, in 2003, an experiment with computer-assisted language learning (CALL) was conducted by Wang Yuwen in teaching intensive reading to their graduate students in Beijing Institute of Technology. CALL could be served differently in the field of language teaching and language learning and has been proved to be an effective tool for improving the quality of language education (Sullivan, 1993; Warschauer, 1998; Shen, 1999). And now, internet-based language laboratory (IBLL) was popularly used in teaching students English. There were many researches (Önkaú, 2009; Yi \& Gao, 2011; Ustatia \& Ismail, 2013) on language laboratory. IBLL could be served differently in the field of language teaching and language learning, but there was few research on IBLL used in teaching non-English-majored graduate students’ English.

With the development of technology of internet-based language laboratory, in the post-massification period, many universities and colleges have built internet-based language laboratory to help teachers to teach non-Englishmajored graduate students to solve the problem of shortage of the English teachers in China. Faced the problem of the shortage of English teachers, we decided the experiment with IBLL in teaching intensive reading to our non-English-majored graduate students, providing them with more chances to practice English even simulate English in a real environment in IBLL.

The purpose of this study was to investigate the impact of integrating BLL in teaching intensive reading at non-English-majored graduate level. More specifically, this study attempted to answer the following questions:

1) Compared with a teacher-dominated approach with the control group (CG), has the IBLL English instruction method with the experiment group (EG) done a better job in enhancing students' productive skills?

2) Are there significant differences between males and females, as a teacher-dominated approach with CG is compared with the IBLL English instruction method with EG?

\section{Theoretical Bases}

According to the theory of Constructivism, knowledge is not taught but is learned by the learner himself through constructing the new knowledge on the basis of old knowledge, under certain settings, with the help of others, such as the teachers or learning partners, utilizing certain study resources. So the student is the center of teaching and student-centered methodology should be used. That is to say, the student is the center of teaching and the teacher works as the organizer, facilitator and motivator, utilizing setting, cooperation and dialogue to motivate students' interests, activities and creatives. Teachers should meet the students' needs. IBLL can help students learn in this way.

\section{Research Methods}

\subsection{Subjects}

In September 2013, 116 first-year non-English-majored graduates in 4 classes from Yangtze University were as the main language. Their majors are chemistry, agriculture, plant protection, animal medicine, animal science, finance and biological technology participated in this study. Among the 116 subjects, 60 were females and 56 males, average age 22 with Chinese. All 116 students who had learned graduate English first semester and had passed CET4 were divided into the control group (CG 58 students) whose English entrance examination scores vary from 50 to 110 and the experiment group (EG 58 students) whose English entrance examination scores vary from 60 to 110, randomly. Their level of education, family background, age, personality and life experiences and other factors were same, that was to say, their overall learning and cognitive abilities were almost equal.

\subsection{Questionnaires}

To gain better understanding of the non-English-majored graduate student feedback about the English course, two different sets of questionnaires were designed in Chinese version, one (13 items) for EG and the other (11 items) for CG, which were given and completed in 30 minutes in class in November, 2013 under the teachers' supervision. We collected all the questionnaires, all 116 responses valid. 


\subsection{The T-Test}

In order to find out which method (IBLL English instruction method and a teacher-centered approach) was proved superior in relation to the attainment of a variety of language teaching and language learning, we adopted the independent sample t-test to compare students' average scores of their entrance and end-of-the-term examination on the basis of two samples, and to exanimate if there are significances between males and females in two groups. However, the t-test requires that "the two populations being compared should be approximately normally distributed and have equal variances” (Anthony Woods et al., 2000: p. 187).

\subsection{Data Collection and Data Procedures}

Data collection was conducted through the questionnaires, entrance examination and end-of-the-term examination. The questionnaires were written in Chinese and handed out to the students during the class session so as to save time and avoid ambiguity in understanding, and if any, the teachers would be of help. The entrance examination and end-of-the-term examination were given to them in the different time after the questionnaires were completed.

The results of the questionnaire and scores tests are inputted to computer and SPSS +13.0 statistical analysis was adopted to make analyses.

\section{Teaching and Learning Setting}

The teachers chosen for CG and EG have the same educational backgrounds, more than 10 years teaching experience and have all studied abroad for half a year. The syllabus for their instructional guidance is the same. And they adopt the similar teaching plans with the same textbooks in the same instructional hour a week. But variations exist in the English teaching and English learning environment for the two groups, CG and EG (see Table 1).

\subsection{The Control Group}

Non-English-majored graduate students have two class hour (90 minutes) to meet with the teacher per week for intensive reading. There are 3 disadvantages for non-English-majored graduate students to learn English. Firstly, CG in the traditional class, the teacher dominates the class by explaining everything in detail from words to texts while students just passively listen to the teachers' explanations about words or texts. Secondly, non-Englishmajored graduate students who do not know if they understand texts or have difficulties except they were provided the tasks by the textbook. Finally, CG's class size is much larger, about 80 students in each class, which means that students do not have enough chances to practice English, even some of them cannot listen to the teacher's voice clearly.

\subsection{The Experimental Group}

Non-English-majored graduate students in CG could depend on the teachers' explanations on everything from English words to texts while non-English-majored graduate students in EG could not depend on the teacher, they have to depend on themselves to do a lot. Firstly, they must study English texts carefully with the help of the online courseware. In order to understand the texts, they need perform the tasks in reading sections including the global reading and the detailed reading from the courseware. Secondly, they have two class hours to meet the instructor for intensive reading per week. In order to ensure the learner-centeredness, the teacher did not explain the texts in detail and students did most of the talking exercise during the class time. Thirdly, the class size is not large, about 50 students in one class, which gives more students more opportunities to practice and simulate English via internet. Finally, the teachers could display the content of courseware who wanted to teach students

Table 1. A contrast of CG and EG in teaching and learning setting for intensive reading.

\begin{tabular}{ccccc} 
& IBLL & Teaching approach & Class size & Learning flexibility \\
\hline CG & No & Teacher-centeredness & About 80 & A little \\
EG & Yes & Learner-centeredness & About 50 & Much \\
\hline
\end{tabular}


through the projector; even students could get help from other people such as English native speakers or a professional person in a field via the internet.

\section{Results}

Whether there were significant differences between CG and EG, and whether there were significant differences between males in two groups, females in two groups, we analyzed the data of the questionnaires and their average scores for two examinations (entrance examination and end-of-term examination).

\subsection{Results of the Questionnaire}

\subsubsection{IBLL Promoted Non-English-Majored Graduate Students' Autonomy}

As shown in Table 2, there was a sharp contrast in non-English-majored graduate students' time to spend in previewing texts before class between CG and EG. Only 27.2\% of non-English-majored graduate students in CG previewed texts at least twice before they visited the internet website courseware while $80.9 \%$ of non-Englishmajored graduate students in EG did the similar thing. One possible factor to the phenomenon is that CG could depend on the teacher to help them to explain everything from words to the texts, but EG must rely on themselves and the courseware from the internet-based language laboratory to make itself understand the texts. Therefore, EG must experience more pressure to push them to work harder. We also could find that previewing the texts before class is very good habit. Without previewing texts before class, many non-English-majored graduate students could not understand texts better, could not participate more relevantly in class activities and could not enhance non-English-majored graduate students to develop their learning autonomy.

\subsubsection{IBLL Helped Build up Non-English-Majored Graduate Students' Confidences}

"No pains, no gains!" As non-English-majored graduate students in EG spent more time to preview and learn texts, they were more confident about their achievements than that of CG. As shown in Table 3, we could see that CG made a little progress in productive skills: listening, speaking, reading, writing, translating while EG made much progress in productive skills: listening, speaking, reading, writing, translating. What's more, EG found that they became more interested in learning English. In turn, EG performed better in their end-of-term-of examination than that of CG (see Table 4).

\subsection{Results of the T-Tests}

\subsubsection{Results of the T-Test about Entrance Examination, End-of-Term-of Examination, the Oral} Test, Writing and Translation

On January 9, 2014, all the 116 non-English-majored graduate students attended the same end-of-term examination

Table 2. Contrasts of CG and EG to spend time in previewing texts before class.

\begin{tabular}{cccccc}
\hline Groups & Numbers & 3 times & 2 times & 1 time & 0 time \\
\hline CG & 58 & $5.1 \%$ & $22.1 \%$ & $52.3 \%$ & $20.5 \%$ \\
EG & 58 & $35.6 \%$ & $45.3 \%$ & $18.4 \%$ & $.7 \%$ \\
\hline
\end{tabular}

Table 3. Students' feedback of progress in productive skills.

\begin{tabular}{ccccc}
\hline Skills & Listening & Speaking & Reading & Writing \\
\hline CG (58) & $79.5 \%$ & $77.5 \%$ & $72.3 \%$ & $65.4 \%$ \\
EG (58) & $91.2 \%$ & $94.3 \%$ & $78.1 \%$ & $91.3 \%$ \\
\hline
\end{tabular}

Table 4. Students average scores between Entrance examination and end-of-term-of examination.

\begin{tabular}{cccccc} 
Items & $\begin{array}{c}\text { Entrance examination } \\
\text { (full score 150) }\end{array}$ & $\begin{array}{c}\text { end-of-term-of examination } \\
\text { (full score 150) }\end{array}$ & $\begin{array}{c}\text { Oral test } \\
\text { (full score 20) }\end{array}$ & $\begin{array}{c}\text { Writing } \\
\text { (full score 10) }\end{array}$ & $\begin{array}{c}\text { Translation } \\
\text { (full score 10) }\end{array}$ \\
\hline CG (58) & 80.88 & 78.34 & 12.34 & 7.23 \\
EG (58) & 79.56 & 82.56 & 13.45 & 7.2 & 78 \\
\hline
\end{tabular}


including listening comprehension, reading comprehension, translation, writing and an oral test. After the examination, we got and checked all the marks (see Table 4), then all the marks were inputted into SPSS +13.0 to calculate the mean scores. We found that the data (entrance examination, end-of-term examination, the oral test, writing and translation) were of or close to the normal distribution. Then the independent sample t-test was carried to measure the significant differences in students' average scores of entrance examination and end-of-term examination such as the oral test, writing and translation.

As shown in Table 5, we could see that non-English-majored graduate students' average total scores of entrance examination $(P=.008)$ meant that there was no significant difference according to non-English-majored graduate students' entrance examination, as the significant difference occurs only when the probability (abbreviated as P) is below or equal to .005. That was to say, CG and EG were at almost the same level of English proficiency when they came into the university. However, after a term's learning, changes taken place when they learned English in different environment and with different approaches. End-of-term examination $(P=.004)$ meant that there was the significant difference between CG and EG. Oral test $(P=.004)$ and translation $(P=.002)$ both suggested that there were significant differences between CG and EG, but writing $(P=.064)$ meant that there was no significant difference between CG and EG. So we can safely conclude that integrating IBLL in intensive reading is more useful in improving non-English-majored graduate students' productive skills such as speaking, translation.

\subsubsection{Results of the T-Test about Males and Females in CG and EG}

As shown in Table 6, males $(P=.004)$ suggested that there was the significant difference between CG and EG; and females $(P=.003)$ suggested that there was the significant difference between CG and EG.

\section{Discussion}

There are several reasons to account for the above significant differences.

Firstly, non-English-majored graduate students in CG come to the classroom and just depend on the teacher to explain everything for them in intensive reading class. They feel boring when they attend the English class because they do nothing except just to listen to the teacher. As a result, they have lost their motivation even interest to learn English. However, non-English-majored graduate students in EG have chances to learn, practice English in IBLL integrated into intensive reading. They have to depend on themselves to preview texts before class to make themselves understand texts, and prepare questions or problems from the texts to ask the teacher in English in class or ask the English native speakers even the professional persons in the special field in IBLL with the help via the internet, which may stimulate their motivation and interests in learning and practicing even using English often. At the same time, depending on themselves to explore everything promotes them to learn English autonomy.

Secondly, non-English-majored graduate students in CG happen to difficulties in learning English intensive reading, they have to depend on the teacher to explain. But the teacher cannot help them explain all the things about texts and solve all the difficulties from texts in all time. IBLL provides EG more chances and different methods to get help to solve difficulties in learning English intensive reading not only from the teacher but also from the courseware or other persons via the internet.

Finally, integrating IBLL in intensive reading, there is different impacts to male and female non-Englishmajored graduate students in CG and EG. Integrating IBLL in intensive reading pushes males and females in EG

Table 5. Results of the t-test about Entrance examination, end-of-term-of examination, the oral test, writing and translation.

\begin{tabular}{lcccccc}
\hline Sig. (2 tailed) & Items & Entrance examination & end-of-term-of examination & Oral test & Writing & Translation \\
\hline Probability & .008 & .004 & .004 & .064 & .002 \\
\hline
\end{tabular}

Table 6. Results of the t-test about males and females in CG and EG.

\begin{tabular}{lccc}
\hline Sig. (2 tailed) & Gender & Males & Females \\
\hline Probability & .004 & .003 \\
\hline
\end{tabular}


to do a lot by themselves, but males and females in CG do less by themselves perhaps they can depend on the teacher.

However, there is no significant difference in students' writing at the end-of-term examination, which may suggest IBLL can help non-English-majored graduate students with writing no more than the teacher can. Perhaps, improving writing ability is not easy to achieve this goal in a short time.

\section{Limitations and Suggestions}

Though the present study has provided a comparatively detailed description of IBLL applied among some first-year non-English-majored graduate students, there are still some limitations of the study. Having the limitations in mind, suggestions for further research, therefore, can be put forward at the same time in order to achieve a lot thorough understanding of IBLL

Firstly, being time limitation (only half year) and other practical restrictions such as the subjects in the study consisted of only 116 non-English-majored graduate students in one university need to be broadened in further research.

Secondly, the instruments used to investigate non-English-majored graduate English teaching with IBLL involve structured questionnaire and tests. The study would be much better, if it were combined with other instruments such as observation, verbal report. More instruments should be used in investigation in further research.

Finally, IBLL applied in non-English-majored graduate English teaching can improve non-English-majored graduate students' English learning and their course learning, but IBLL also works for other subjects such as undergraduate students, we need further research.

Despite of the restraints of the study, it is hoped that it can offer some guidelines for further research on IBLL applied in English teaching.

\section{Conclusion}

One term's experiment has shown that IBLL is an effective method of assisting non-English-majored graduate students to improve their productive skills such as oral English and translation, and to promote their autonomous learning and interests in English. There is a significant difference between CG and EG about males and females in different teaching environment and different teaching methods. We believe that IBLL should be a useful tool to help teachers to teach English and students to learn and use English.

\section{References}

Liu, L., \& Jia, G. (1998). The Multimedia Mix of College English Intensive Reading. Foreign Language Teaching, 71, 1318.

Ustatia, M. K., \& Ismail, I. S. (2013). Challenges Faced by Malaysian Polytechnic English Lecturersin Utilizing Digital Language Lab. Procedia-Social and Behavioral Sciences, 90, 365-373. http://dx.doi.org/10.1016/j.sbspro.2013.07.104

Önkaú, N. A. (2009). Poetry Teaching in Laboratory Setting. Procedia Social and Behavioral Sciences, 1, 590-595. http://dx.doi.org/10.1016/j.sbspro.2009.01.106

Shen, J. (1999). Learner Anxiety and Computer-Assisted Writing. CALL EJ3 (2). http://www.lerc.ritsumei.ac.jp/callei

Sullivan, N. (1993). Teaching Writing on a Computer Network. TESOL Journal, 34-35.

Wang, Y. W., Wu, L. G., \& Sun, D. X. (2003) Integrating CALL in Teaching Intensive Reading at Graduate Level. Teaching English in China, 26, 101-107.

Warschauer, M., \& Healey, D. (1998). Computers and Language Learning: An Overview. Language Teaching, 31 , 51-71. Cambridge: Cambridge University Press. http://dx.doi.org/10.1017/S0261444800012970

Yi, L., \& Gao, X.-Y. (2011). Practice of Autonomous Learning Mode under the Language Laboratory Environment. Research and Exploration in Laboratory, 7, 327-329. 